\title{
CASE REPORT OF NEGLECTED CORN OF FOOT FOR TWENTY YEARS LEADING TO SQUAMOUS CELL CARCINOMA FOOT
}

K. Nischal ${ }^{1}$, M. Madan ${ }^{2}$, Srikanth. T ${ }^{3}$.

\section{HOW TO CITE THIS ARTICLE:}

K. Nischal, M. Madan, Srikanth. T. "Case report of neglected corn of foot for twenty years leading to squamous cell carcinoma foot". Journal of Evolution of Medical and Dental Sciences 2013; Vol2, Issue 28, July 15; Page: 5277-5279.

ABSTRACT: Squamous cell carcinoma (SCC) is a common type of skin cancer. Infection with human papillomavirus (HPV), the cause of genital warts and many mucosal SCCs. It is the cause of carcinoma cuniculatum but rarely causes other forms of cutaneous SCC. A corn is a specially shaped callous of dead skin.

KEYWORDS: Corn, SCC, Foot.

\section{REVIEW OF LITERATURE:}

- Squamous cell carcinoma (SCC) is the second most common form of skin cancer.

- Squamous cell carcinoma usually occurs on sun-damaged skin, especially in light-skinned individuals with a long history of chronic sun exposure.

- Squamous cell carcinoma requires treatment to prevent it from becoming too invasive.

- If it is caught early and treated appropriately, squamous cell carcinoma rarely spreads (metastasizes) to lymph nodes or to internal organs.

However, if it is neglected, squamous cell carcinoma can cause tissue destruction or it may spread internally, causing serious health problems and even death.

A corn is a callous of dead skin that usually occurs on thin hairless and smooth skin surfaces, especially on the dorsal surface of toes or fingers. The treatment of choice is excision and providing care not to cause excessive pressure or friction to the part.

\section{CASE REPORT:}

- 60 yr old male patient presented to us with history of wart present since twenty years which has increased in size for the past two months associated with pain

- No other associated complaints present

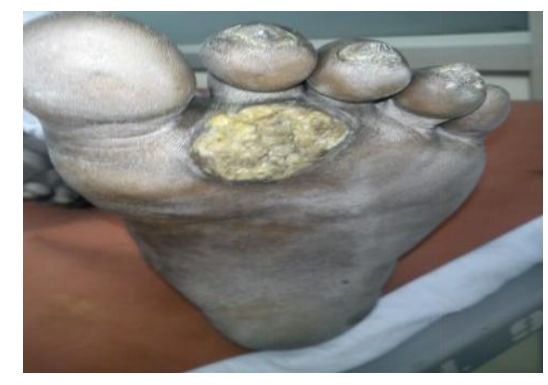

Fig-1 


\section{CASE REPORT}

\section{CLINICAL EXAMINATION:}

An exophytic growth of size about 5 X $6 \mathrm{~cm}$ is present in sole of the foot with irregular borders (FIGURE 1)

X RAY FOOT: (FIGURE 2)

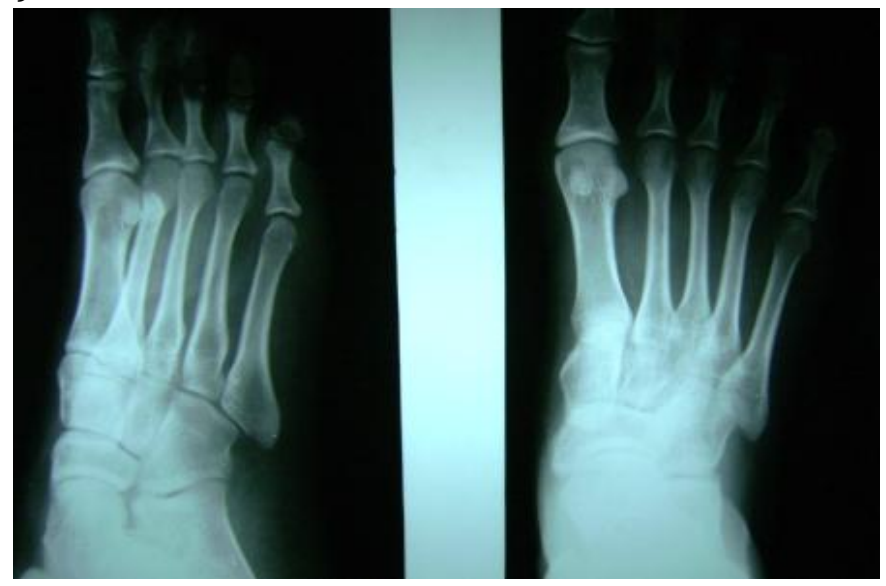

FIGURE 2: No bony involvement is seen

- EDGE BIOPSY of the exophytic growth was done.

- HISTOPATHOLOGY.

Features were consistent with squamous cell carcinoma.

Edge biopsy: showed features of squamous cell carcinoma with thickened keratinised layer. There was no involvement of deeper tissues. Margins were free of malignancy.

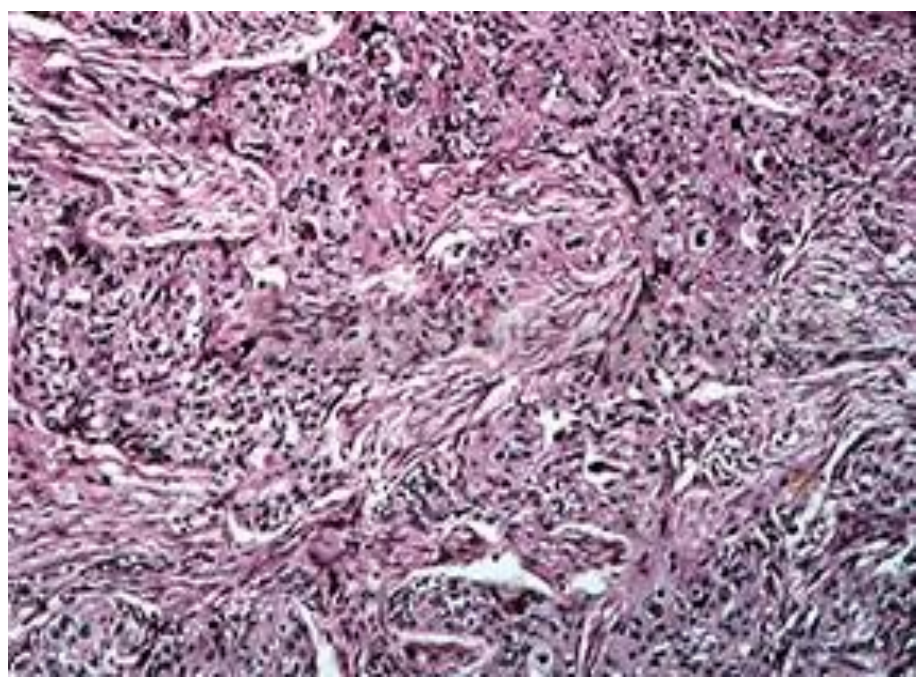

FIGURE 2:

MANAGEMENT:

- As there was involvement of the inguinal group of lymph nodes external beam radiation therapy was given and down staging of the tumour was done.

- BELOW KNEE AMPUTATION WAS DONE. 
CONCLUSION: Squamous cell carcinomas of the foot are likely underreported and frequently subject to inappropriate initial treatment. Most patients have identifiable risk factors for SCC that can aid in formulating an appropriate differential diagnosis. Despite frequent suboptimal initial treatment, most patients are candidates for complete or partial limb salvage, with generally good oncologic and functional outcomes expected.

Acknowledgements: sincerely thank all my post graduates, interns and my staff

\section{REFERENCES:}

1. Rossis CG, Yiacoumettis AM, Elemenoglou J: Squamous cell carcinoma of the heel developing at site of previous frostbite. R Soc Med 75:715-718, 1982.

2. Kong M-F, Jogia R, Jackson S, Quinn M, McNally P, Davies M: Malignant melanoma presenting as a foot ulcer (Case report). Lancet 366:1750, 2005

3. Al-waiz MM, Maluki AH, Squamous cell carcinoma complicating prurigo nodularis, Saudi Med journal, 2000 Mar, 21/3:300-1

\section{AUTHORS:}

1. K. Nischal

2. M. Madan

3. Srikanth. T

\section{PARTICULARS OF CONTRIBUTORS:}

1. Associate Professor, Department of General Surgery, SDUMC.

2. Professor \& HOD, Department of General Surgery, SDUMC.

3. Post Graduate, Department of General Surgery, SDUMC.

\section{NAME ADRRESS EMAIL ID OF THE} CORRESPONDING AUTHOR:

Dr. K. Nischal,

Dept of General Surgery,

Sri Devaraja Urs Medical College,

Tamaka, Kolar.

Email-knischal697@gmail.com

Date of Submission: 28/06/2013.

Date of Peer Review: 28/06/2013.

Date of Acceptance: 10/07/2013.

Date of Publishing: 15/07/2013 